\title{
What We Have Lost: Domestic Dogs of the Ancient South Pacific
}

\author{
Carys Louisa Williams ${ }^{1}$, Silvia Michela Mazzola ${ }^{2^{*}}$ \\ Giulio Curone ${ }^{2}$ and Giovanni Quintavalle Pastorino ${ }^{2,3}$ \\ ${ }^{1}$ Institute of Zoology, Zoological Society of London, Regents Park, London, NW1 4RY, \\ United Kingdom. \\ ${ }^{2}$ Department of Veterinary Medicine, Università degli Studi di Milano, Milan, Italy. \\ ${ }^{3}$ Faculty of Life Sciences, The University of Manchester, Oxford Road, Manchester, M13 9PT, \\ United Kingdom.
}

Authors' contributions

This work was carried out in collaboration between all authors. Author CLW designed the study and wrote the first draft of the manuscript. Authors SMM and GQP managed the literature searches. All authors read and approved the final manuscript.

Article Information

DOI: $10.9734 / A R R B / 2018 / 40377$ Editor(s):

(1) George Perry, Dean and Professor of Biology, University of Texas at San Antonio, USA. Reviewers:

(1) Robin Cook, South Africa. (2) Tamer Çağlayan, Selcuk University, Turkey. (3) El Mahdy Cristina, University of Agricultural Sciences and Veterinary Medicine Cluj-Napoca, România. Complete Peer review History: http://www.sciencedomain.org/review-history/23786

Review Article

Received $7^{\text {th }}$ January 2018

Accepted $19^{\text {th }}$ March 2018

Published 23 ${ }^{\text {rd }}$ March 2018

\begin{abstract}
In the thousands of years that followed dog domestication, wherever humans went, dogs surely followed. However, the tale of the dog in the ancient South Pacific is often an overlooked one. A small, bandy-legged dog, seemingly not much use for anything but food, this canine could easily be overshadowed in history by more accomplished breeds; the sled dogs of Siberia, the sight hounds of the Middle East, the herders and guarders of Europe, or the practical retrievers of North America. In actuality, tracing the journey of this domesticate could help us to work towards an answer in the mystery of the origin of the first South Pacific colonists. Through discussing the journey and presence of the domestic dog following one of the last great feats of human migration, valuable insight can be gained surrounding one of the longest-standing human-animal relationships. Over time, the closeness of man and dog in the South Pacific persisted, entrenched in folklore and material culture, with this landrace of dog only facing an untimely demise when it was usurped and genetically diluted by European breeds.
\end{abstract}


Keywords: Dog; Canis lupus; Polynesia; South Pacific; human-animal relationship; anthrozoology.

\section{INTRODUCTION}

The colonisation of the South Pacific is one of the most impressive feats of migration in human history. With the exceptions of Madagascar and Iceland, these were the last islands to be colonised by people [1]. As part of this colonisation, journeys of thousands of miles at sea in canoes to unknown land [1], why was it considered appropriate to bring dogs? The tale of the dog in the South Pacific is often an overlooked one, perhaps due to this particular strain of domestic dog becoming extinct by the mid to late 1800s [2]. Prior to this, very few visitors to this part of the world deemed it necessary to comment at length on such an animal [2]. Regardless, making use of what is known of the Polynesian dog, it is possible to explore its role in societies where additional dependent animals would, at first glance, appear detrimental. The ecology of the islands provides little to no role for the dog as a hunter; no predators big enough to need guards; no considerable land distances for pack dogs to traverse; no other domesticates to herd; and ample alternative food resources available from the sea. Despite this, the dog persisted on these islands and had a variety of roles in the culture of the people who brought them there.

\section{DISCUSSION}

The majority of the inspiration for this piece is based on the work of Margaret Titcomb, who, on behalf of the Bernice Pauahi Bishop Museum Library Honolulu, Hawaii, collated essentially all the information available on the history of dogs in the South Pacific at the time [2]. A notable amount of Titcomb's original research and sources is based on personal interviews and therefore exists only under Titcomb's interpretation and translation. Much of the material on this topic comes from Hawaii, Samoa and New Zealand, but discussion of dogs on other islands will be included where possible. It would appear that some islands never had dogs; perhaps they were eaten en-route, or they went extinct some time in antiquity archaeological evidence of their existence is yet to surface. Luomala [3] also presents the agreeable criticism that much of the 'original' literature on this subject is unquestioned second or third-hand interpretations of comments by 'explorers', not scientists or anthropologists. Many are likely not referring to pure Polynesian dogs, but to those that have hybridised with European dogs. On a similar note, some original sources by indigenous authors may have changed details to suit judgemental European tastes, namely the dislike of eating dogs. His Hawaiian Majesty Kalakaua [4] makes no mention of eating dog meat or its use in ritual offering within his book of traditional Hawaiian folklore, although older ethnographic evidence would suggest it was highly favoured by chiefs, especially for celebrations and offerings. With this in mind the breed will be discussed with as much amplitude and accuracy as sources will allow.

Additionally, the term 'South Pacific' will be used somewhat synonymously with 'Polynesia', the triangle of islands from Hawaii down to Easter Island and across to New Zealand [1].

\subsection{Phenotypic and Behavioural Descriptions}

"The dogs are in general useless for anything" [5].

The South Pacific dog, from the few descriptions available, was not a noble creature. By all accounts these dogs were noticeably small, often likened to a terrier or a 'turnspit' [3,6-9], but without the same level of utility. The turnspit or 'turnspete' [10] was a British dog breed described between the 16th and 19th centuries; it was small enough to run in a wheel that turned roasting meat on a spit above a fire, usually in a public house. The coat of dogs of the South Pacific were said to have come in a variety of colours, in long- and short-haired varieties $[2,3$, $11]$. White was a desirable coat colour $[2,12]$, curly tails were expected $[2,12]$, and it was rare to see dogs with drop ears $[3,6]$; the latter was considered an undesirable trait [2], as Titcomb comments: 'hanging ears were not considered the sign of a good dog' [2]. There were likely a number of variations of the Polynesian dog, but only the New Zealand 'Kurī' has been described as notably different to the Hawaiian 'Poi' or "îlio'; the former was usually of bigger stature and more often exhibiting a long-haired coat $[11,13]$.

Unfortunately, there are no photographs, drawings or art work which can be undeniably confirmed as a visual representation of the Hawaiian 'Poi' or 'Tilio' breed of the Polynesian dog. Possible images of these dogs can be seen in Luomala's 1962 piece on Eighteenth-Century sketches of the Polynesian Dog [12] and in Titcomb's 1969 book [2]. However, a taxidermy 
specimen of the New Zealand 'Kurī' (affectionately named 'Whitey') does exist and is held by the Museum of New Zealand Te Papa Tongarewa, Wellington; whilst the quality of the taxidermy is questionable, it provides a suitable visual of how the dog looked [See Fig. 1].

An interesting feature is the consistent descriptions of these dogs commonly possessing bowed front legs [2,9]. It is certainly worth considering whether this could be an expression of osteochondrodysplasia, hypochondroplasia or an antebrachial growth deformity; these conditions often have a genetic basis, a link to nutritional deficiencies or a combination of the two. A few modern breeds, such as Skye Terriers [14], can develop bowed or twisted legs due to a faulty gene causing interrupted and uneven bone development. Alternatively, considering the dogs were fed mainly on starchy root vegetables like taro and yams $[2,9]$, it is possible they were suffering from rickets or secondary nutritional hyperparathyroidism, which are both linked to restrictive diets, and particularly diets low calcium $[15,16]$. There is some evidence that the diet of these dogs was restrictive enough to affect other parts of their physiology; Svihla [17] found an unusually high prevalence of dental carries in the teeth of Hawaiian dogs and linked this tooth decay to a diet high in sugar and starch. WoodJones [9] had previously described the cranium of the Hawaiian dog as possessing 'primitively large' teeth with signs of jaw muscle atrophy, more suited to the mastication of a soft vegetable diet.

The dogs of Polynesia did not, or seemingly could not, bark $[2,3,6]$. Nor did they howl, yodel or sing as other bark-less dogs do, like the basenji, New Guinea singing dog or the dingo $[18,19]$, much to the surprise of the Europeans who encountered them: "I know of no race of human beings unable to speak, and when I first heard of a class of dogs unable to bark, I was exceedingly incredulous, for I imagined both equally natural gifts. But these animals can only whine and yelp, and this they do in the most piteous tones imaginable" remarked Stone of the dogs in New Guinea [19]. Some Polynesian dogs apparently learnt to bark, perhaps due to interactions with European dogs; a similar scenario can be seen in modern day kennels when bark-less dogs learn this noisy trick from their kennel mates, often much to their owner's dismay [20]. Interbreeding with European dogs may also have provided them with this ability. Polynesian dogs were highly fearful and often displayed anxious rather than confrontational behaviours [2,11]. This type of temperament in modern dogs is often the result of poor socialisation in the early stages of a puppy's life, as they do not learn to be tolerant of new circumstances or people [21]. This is one possible explanation, although there are very few comments on the raising of the dogs, aside from the frequent breastfeeding of puppies by Polynesian women [22,2]. It was seemingly agreed that these were not intelligent dogs [9, 11,23] or in Forster's blunt words, "They are exceedingly stupid . . . and lazy beyond measure" [6]. In modern terms we would likely categorise them as a breed with low-drive, lowaggressivity and low-reactivity [24], terms generally associated with non-working breeds and lap dogs.

It is unlikely that a line of the Polynesian dog has survived to modern times without some level of admixture with European dogs, which had been introduced by the Spanish and the English around the 18th Century [26]. Attempts were made in the 1960s by Jack L. Throp of Honolulu Zoo, Hawaii to recreate the Hawaiian Poi dog [23], much like the 'TaurOs' project to 'recreate'

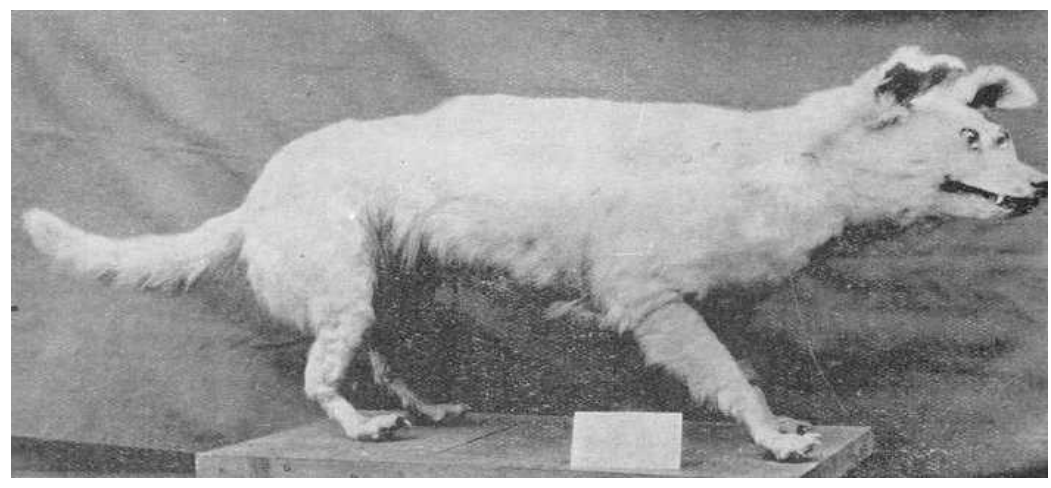

Fig. 1. Taxidermy Kurī from the Dominion Museum Collection, 1924 (Now the Museum of New Zealand Te Papa Tongarewa, Wellington) [25] 
Aurochs in Europe [27]. This is achieved by breeding animals unrelated to the original species, but similar enough in morphology to look like a representation of the original. Extracts from the Honolulu Advertiser imply the project began in 1967, with at least one 'Tilio' or 'Poi' dog present at the zoo from 1969 [28,29]. Within one of these newspaper excerpts, there is the phrase 'Poi dog has 16 puppies' [30], but as 'Poi' was a common name for mongrels, and small dogs are physically incapable of carrying 16 puppies to full-term, this is unlikely a reference to Throp's dogs. Seemingly, the last mention of this project is by Titcomb [2]. It is unclear why the project failed to progress any further, although the zoo went through a significant revival around this period [31] and it is likely that dogs were not considered a high priority project.

\subsection{The Origins of the Polynesian dog and Implications for Studies on Human Migrations}

The idea of using domesticates to investigate the path of human migration is not a new one. WoodJones [8] was likely the first to consider the New Guinea Singing Dog for this purpose, but with only morphological features to rely on and an increasing level of hybridisation with European dogs, this idea failed to gain momentum [13]. With access to modern genetics, there has been renewed interest in this area. Not only can we begin to map the Polynesian dog on the Canis lupus familiaris family tree but also its origins could provide details about the route the first Polynesians followed into the South Pacific. At present dating and establishing the birthplace of the expansion into Polynesia remains unresolved, with estimates based on carbon dating, archaeology, linguistics and genetics varying by from 5000 years ago to $1 \mathrm{AD}[32,33]$. Any additional information to solidify estimates or eliminate any of the numerous models is therefore of great interest. Key to identifying the Polynesian dog, it is important to divulge if they are Canis lupus familiaris, or perhaps a strain of their geographical neighbours, the Australian Dingo (Canis lupus [familiaris] dingo) or New Guinea Singing Dog (Canis lupus [familiaris] dingo hallstromi). The dingo presents somewhat of a mystery in world history, being the only piece of Neolithic culture to have reached isolated mainland Australia some-time around 4600 years ago [34]. The New Guinea Singing Dog (NGSD) is a feral and reproductively isolated canid living in the forests of New Guinea [35]. It is physiologically very similar to the dingo, although much smaller and with a very unique ability to 'sing'. Studies on the NGSD often appear skewed by a desire to prove their antiquity and legitimacy as a distinct species $[36,37,38]$ despite inconclusive evidence, likely for conservation purposes, but archaeological evidence suggests they have been present in New Guinea for at least 2000 years [39]. A mitochondrial DNA (mtDNA) analysis was performed to investigate the origins of all three by Oskarsson et al. in 2011 [40]. By looking for distinctive haplotypes or 'allele clusters' within the mtDNA this allows you to estimate how large a founding population may have been, whether there was gene flow or isolated breeding and which dogs world-wide share this ancestry. PreEuropean contact samples were obtained from Hawaii, New Zealand and the Cook Islands for the Polynesian dogs and these were shown to carry only two haplotypes, Arc1 and Arc2 [32, 40]. Dingoes carried only the A29 haplotype or haplotypes one mutation away from $A 29$, whilst NGSD presented A29 or A79, the latter of which is one substitution away from A29 [32,40,41, 42,43]. Interestingly, these haplotypes are present only in South East Asian dogs, with no evidence for them west of the Himalayas, or in Taiwan or the Philippines. A number of models explaining the expansion into Polynesia have Taiwan as a likely island of origin, notably Diamond's [44,45] express train model. Oskarsson et al. [40] feel their research disproves these theories, or at least confirm influence from other locations and cultures [32]. As for the dogs, dingoes, NGSD and Polynesian dogs therefore likely shared an introduction route through mainland South East Asia, and then experienced separate founder bottleneck events preventing the addition of any new mtDNA haplotypes. Whilst this study unfortunately does not contain enough samples of Polynesian dogs to provide a precise estimate for the time of their arrival, it suggests a preNeolithic introduction from East Asia for all three canids, based on their reproductive isolation from other dog populations. It is certainly curious how the little Polynesian dog was so morphologically and behaviourally different from both the dingo and the NGSD, despite their shared ancestry, but this in itself highlights the versatility of the dog phenotype [46].

\subsection{The Role of the Dog in the South Pacific}

\subsubsection{Food}

There is no doubt that a main role of the dog in most Polynesian societies was to provide a 
source of food. When the dogs first arrived with the Lapita colonists it is doubtful they were a significant part of the diet [47] as very few remains are found, especially in comparison to marine foods, but later ethnographic evidence suggests they were widely consumed. In some cases, the word for food become synonymous with the word for dog: poi in Hawaiian and 'ina'i in Tahitian [48]. However, the impression should not be given that eating dogs was taken lightly or an everyday occurrence. Unlike in present day South East Asia where dog meat is a food associated with necessity and rural farmers [49], dog meat was often reserved specifically for the chief's table or celebratory feasts. Puppies were preferred [2], these were considered more succulent, although there are examples of islanders who ate only older dogs, which was apparent in the Gilbert Islands [2]. Taking an evolutionary look at the consumption of these dogs, Driscoll and MacDonald [50] conclude from Titcomb's work that the dogs provided a channel through which to turn scraps and waste into valuable protein. Instead of the dogs being costly dependents by needing to be fed, they provide a profitable return to their owners. On the topic of whether the dog is friend or food to the Polynesians, Podberscek [49] provides an interesting study based on modern day South Korea, a country frequently criticised for its tradition of consuming dog (and cat) meat; whilst the survey showed $70 \%$ of respondents saw no problem with consuming meat from dogs, they also made clear distinctions between dogs that were 'pets' and those that could be consumed. In South Korea, many smaller breeds are kept as pets, whilst 'yellow-furred' dogs are denoted as food and historically, dogs were not only raised for food, but some were used as guards; these were neither kept as pets in-doors nor fattened for eating. It is reasonable to suggest the Polynesians were more than capable of appreciating their dogs in both a companion role and as a source of food, but also that with increasing interbreeding with European breeds occurred they were more reluctant to consume 'useful' dogs.

\subsubsection{Dog deities}

The dog never received the same level of cultural importance in the South Pacific as the pig did [11]. It was not as valuable in terms of food, being significantly less nutritious than a pig, which affected its importance in society. In Wamira, Melanesia, the pig became a metaphor for controllable female sexuality with complex systems of ritualistic piglet exchange to maintain power in male-to-male relationships in a matrilineal society [51]; nowhere in the region do dogs appear to have become such an intrinsic part of the societal structure. Regardless, through two choice examples, insight can be provided into the spiritual aspects of the dog in the South Pacific.

\subsubsection{Dog deities: Hawai'i}

Dogs feature frequently throughout Hawaiian folklore, proverbs, fables, and even in children's chants [52]. An interesting dichotomy existed when it comes to how the dog is portrayed; the dog is sometimes a symbol of wealth and prestige, used to show status or embody a noble warrior, whilst on the other hand the dog represented a thief and a lazy scrounger, often used as a comic scapegoat for poor fortune or omen of death [53]. A playful example of this is the tale of PuaPuaLenaLena, a kupua (shapeshifting demon) [4,54,55]; PuaPuaLenaLena, in the form of a dog, is a notorious thief, known for stealing alcohol. In one story, PuaPuaLenaLena uses his stealth to return the Kiha-pu magic conch shell to King Kiha, in order to spare the life of his drunkard master who is being held prisoner for PuaPuaLenaLena's crimes. He is celebrated upon his return as a brave and loyal dog, having outwitted and outrun bands of demon men, until he drops dead at the feet of the king; he is then mourned only by his old master.

\subsubsection{Dog deities: Samoa}

Turner's [56] experiences in Samoa and the South Pacific, as a $19^{\text {th }}$ century missionary, makes particular mention to the wide spread zoolatry in the region. Each house and each individual were under the guidance of a particular god, and each of these 40 gods was associated with an animal form. For a Samoan to subsequently eat or injure the animal incarnation of his god would be followed by "the god's displeasure in sickness or death of himself, or some member of his family" [56]. It was not unusual for a family's household god to be in the guise of a dog, and this family would then abstain from consuming dog meat [56]. 'Saleveo' was a war god for a number of Samoan villages, who 
was said to take the form of small white dog; which notably defies the European description of Polynesian dogs appearing 'cowardly'. If the dog dashed ahead, wagging its tail and barking, this was considered a sign of imminent victory; for the dog to retreat or howl would suggest defeat or great losses [56]. Saleveo also had the ability to take the form of the moon, a great honour in Samoan culture, which relied on a lunar calendar; it is easy to see how a curled up white dog could be a visual metaphor for the moon.

\subsubsection{Dogs in material culture}

A great deal of Polynesian material culture was produced from wood or vegetable fibres, and this has restricted what has been preserved in the archaeological record [57]. Luckily, many dog-based products made use of their teeth, which are well persevered, so evidence can be found for a range of uses for dogs in material culture in early contact Polynesia. Descriptions in this section will be kept very brief; this section is only to provide examples of dog-related objects rather than an in-depth study of Polynesian life and cultural practices.

\subsubsection{Dog teeth}

There is extensive use of teeth throughout the South Pacific and dogs' teeth are no exception. The Bishop Museum, Honolulu, owns 13 examples of hula ankle rattles created from dogs' teeth; just one of these ankle rattles is constructed from a total of 11,218 teeth, which would have required 2,805 dogs [2]. Men wore these during traditional hula dance performances, although the teeth of pigs were also acceptable [58]. These ankle rattles were also worn during dances by men of the Sandwich Islands [2]. Teeth were commonly used for jewellery, by boring holes through each tooth and passing string or other connective fibres through them. Necklaces of dogs' canine teeth were used to ward off evil spirits [2]. Bracelets are more commonly found constructed from pig teeth; no dog tooth examples have been found which predate the 17th century, so it is difficult to say if this was a use for dogs' teeth in antiquity [2]. Dog bones and teeth were one of the most commonly used items to construct fishhooks [59]. Bird and pig bones were also used for this purpose.

\subsubsection{Dog hair}

Gorgets (breast plates), or taumi, were a sign of military prowess and insignia of rank across the Society Islands. Usually these were fringed with feathers, but white dog fur was used when available [60]. This may have been why longhaired dogs were more prevalent than shorthaired on the Tuamotu Islands; additionally, by eating all the short-haired puppies, only those with long-hair reached sexual maturity $[2,60]$ and therefore reproduced. Similarly, the long-haired Kurī dog of New Zealand was used to create hair fringing on cloaks and spears [2]; Kurī selected for the finest cloaks would receive preferential treatment and be kept indoors to keep their white coats pristine [2].

\subsubsection{Figurative art}

Figures representing the dog can be found in both practical and artistic spheres in the Polynesian archaeological record. New Zealand hails more findings than most islands, with one of its oldest artefacts being a carved wooden dog, which was found in Moncks Cave [61]. Titcomb [2] describes this particular artefact as a toy, but this doesn't appear in other literature on the object. Titcomb [2] also describes a Maori carved bowl, with the head, feet and tail of a dog, as an example of dogs carved into everyday objects. In Hawai'i, there exists a form of rock art referred to as petroglyphs, which are suspected to be between 900-300 years old [62]. Some are carved into the rock-face; others are produced with products like charcoal. The most common animal depicted is suggested as the figure of a dog [62], although in some cases these images may also be depicting pigs, as there are few distinguishable features to these animals [See Fig. 2]. The use of carved wooden figure-heads on Samoan canoes is described by Turner [56]: 'they had a figure-head with some rude device of a human figure, a dog, a bird, or some-thing else, which had from time immemorial been the "coat-of-arms" of the particular village or district to which the canoe belonged'. Canoes were used for war and peace missions, so the figure head could therefore be used to identify enemies or allies. The dog was one of the animal forms for the Samoan god of war, Saleveo, so his presence on a war canoe is logical. Interestingly, Samoa has been noted as lacking in figurative art prior to European contact [63], which could contradict Turner's assumption this was a long-standing tradition. 


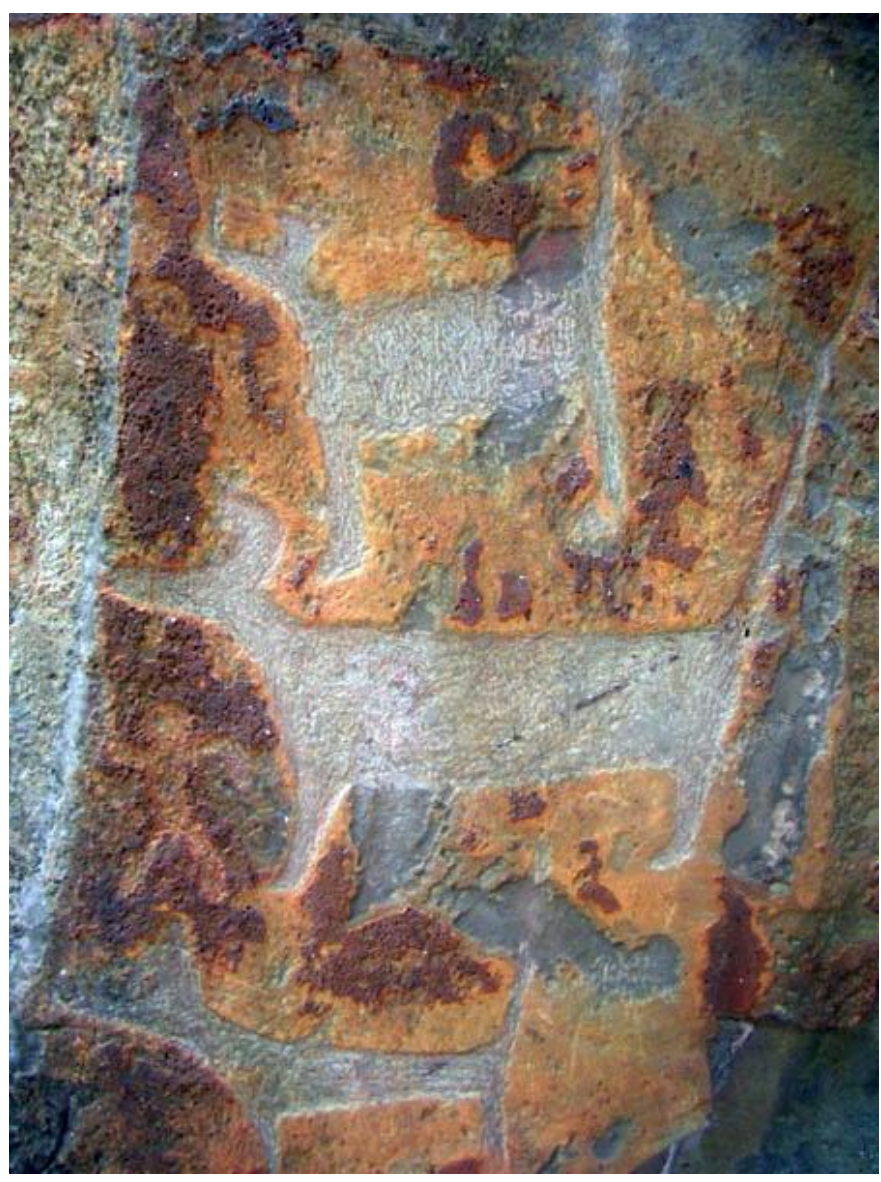

Fig. 2. Dog petroglyphs, Nu'uannu, Honolulu, Oahu, Hawaii. [64]

\subsection{Pet Keeping and Companionship}

"O ka 'îlio kahu no ka 'îlio hae" - The dog who has a master is the dog who barks the most (Hawaiian proverb).

Titcomb states there is 'no evidence of companionship between man and dog' [2]. However, this conclusion seems to be unfounded, and very much influenced by the definition of a 'pet' held by the European visitors, with later interpretations maintaining this view. Although the dogs were, by European standards, untrained, there appears to have been a stringent level of ownership over the dogs, and with women holding a particular closeness with dogs and especially puppies. Sources from various islands make note of women tenderly breast-feeding puppies, and even rocking them in cradles $[2,5,22]$. Breastfeeding of animals by humans is not as unusual as modern culture would have the reader believe; the suckling of young animals has been used across cultures to promote lactation, drain excessive lactation, harden the nipples prior to child-birth, to feed young animals or to act as contraception [65,66, 67]. Breast-fed puppies in many cases in Polynesia were held in such high esteem they were strictly not to be eaten, so the action of suckling them served no purpose in terms of raising them for meat [2]; it is unfortunate that it is no longer possible to investigate the practical and cultural drivers behind the original breastfeeding practice in this case.

It is perhaps not unreasonable to suggest some of the male explorers who observed these dogs were looking for evidence of 'man's best friend', and to find a relationship only between woman and dog was not sufficient. Luomala [11] writing at a similar time to Titcomb [2] expressed that these dogs were 'a companion, a pet, a scavenger, a sentinel and guardian and an aid in hunting and war', but as to how many of these roles the dog fulfilled and to what extent this varied across the area of study. Dingoes and 
NGSD are or were sometimes used for hunting $[35,68]$; whether they are a help or hindrance is up for debate, since dingoes can actually lower the success rate of a hunt [10] and NGSDs will often steal a kill [68]. The Kurī of New Zealand was apparently an efficient retriever [69], but there are very few accounts of the dogs being used for hunting elsewhere in the South Pacific. This is likely due to the lack of suitable prey in addition a general reliance on marine food and other domesticates. An interesting query could be as to whether dogs depleted any species worth hunting which may have been present originally, for instance ground-laying birds [69, 70] mentions a cull of dogs in Tonga as they had 'destroyed the game'. Invasive species elsewhere have certainly had this effect on native wild life, and the depletion of endemic species in Hawai'i since its colonisation is extremely well documented [71], although, there is no obvious mention of whether dogs had an impact. They certainly have not received the same criticism as the impact of domestic cats or rats [72].

Even if dogs were not helpful companions, the dogs were important pieces of property, as Stone relays [19]: 'A maliciously disposed native dog had been eating up two of the teacher's chickens, and in consequence the teacher had shot the animal . . . the leader stood before me, mad with rage ... in revenge for the loss of the dog. . . a younger son carried a firebrand, threatening to burn the house ... a third son was armed with a club and several spears'. The loss of a dog was clearly not taken lightly. This type of reaction suggests there was a strong sense of ownership over dog, and further similar examples are available; in Hawai'i, when a person died, it was not unusual to kill their dog and bury it with the owner [9], sometimes wrapped in the same manner as a child. In other cases, a mother might choose a puppy to be a 'companion and protector of her child' [2]; if the dog died first, the dog's teeth were made into a necklace, so the spirit could protect the wearer [2]. This was not always the case across Polynesia by any means, whilst it was common in Hawai'i Clark [13] notes 'in New Zealand no clear burial context [for dogs] is apparent'. Interestingly, across the region dog graves outnumber those of pigs $[13,73]$ despite the assumption that pigs were held in a higher regard in Polynesian culture.

\section{CONCLUSION}

Whilst the Polynesian dog may have lacked the obvious functionality of other breeds, its cultural role provides a fascinating insight into the human-animal relationship within South Pacific societies and the wider relationship between humans and domestic dogs. There may be a wealth of similar ethnographic studies on preEuropean contact dogs elsewhere, which may help us produce a less Euro-centric view of the traditional role of dogs in society; there is certainly scope for investigating dogs in Africa [74] and the Americas.

The new sightings of NGSDs in 2017 is also of note, as are the implied intentions to improve genetic research into these elusive canids; this could provide future clarification for the genetics of the Polynesian dog too.

The interest in and use of studying historical dog populations is a growing field. What is often lacking is an interdisciplinary link between studies, creating limitations of impact. As a first attempt to provide an interdisciplinary overview of the Polynesian dog this piece may provide a firm foundation for a researcher relatively new to the topic; the author welcomes future contributions to the topic from researchers with stronger cultural connections to the geographical area discussed.

\section{COMPETING INTERESTS}

Authors have declared that no competing interests exist.

\section{REFERENCES}

1. Gamble C. Settling the Earth: The archaeology of deep human history. Cambridge University Press: Cambridge. 2013;284-295.

2. Titcomb M. Dog and man in the ancient South Pacific with special attention to Hawaii. Bernice P. Bishop Museum Special Publication 59: Honolulu. 1969;6:23:48.

3. Luomala K. A history of binomial classification of the polynesian native dog. Pacific Science. 1960;14(3):193-223.

4. Kalakaua His Hawaiian Majesty. The Legends and Myths of Hawaii - The Fables and Folk-lore of a Strange People. Charles L. Webster \& Company: New York; 1888.

5. Macrae J. With Lord Byron at the Sandwich Islands in 1825. William F. Wilson: Honolulu. 1922;42-43.

6. Forster JR. 1729-1798., Forster, G. 17541794., and Robinson, G., 1736-1801. Observations made During a Voyage 
Round the World [in H.M.S. Resolution] on Physical Geography, Natural History, and Ethic Philosophy, especially on 1. The earth and its strata 2. Water and the ocean 3. The atmosphere, 4. The changes of the Globe 5. Organic bodies, and 6. The human species. Printed for $\mathrm{G}$. Robinson, in Pater- noster-Row: London. 1778; 188-189 [ONLINE] Scanned by Natural History Museum Library, London.

Available:http://www.biodiversitylibrary.org/ item/106982\#page/5/mode/1up

7. Cook J. A voyage to the Pacific Ocean; for making discoveries in the northern hemisphere: Performed under the direction of Captains Cook, Clerke, and Gore in the years 1776, 1777, 1778, 1779, 1780' Vol IIV. New York. 1784;118.

Available:http://tinyurl.com/ps5o7gd

8. Wood-Jones F. The Cranial Features of the Papuan Dog. Journal of Mammology. 1929;10:329-333.

9. Wood-Jones F. The cranial features of the hawaiian dog. Journal of Mammology. 1931;12:39-40.

10. Bradshaw J. In Defence of dogs. Penguin Books: London. 2011;64-65.

11. Luomala $K$. The native dog in the polynesian system of values. in Diamond, S., (eds) Culture in History - Essays in Honor of Paul Radin. Columbia University Press: New York. 1960;190-240.

12. Luomala K. Additional Eighteenth-Century Sketches of the Polynesian Native Dog, Including the Maori. Pacific Science. 1962; XVI:170-180.

13. Clark G. Maori subsistence change: Zooarchaeological evidence from the prehistoric dog of New Zealand Asian Perspectives. 1997;36(2).

14. Gough A, Thomas A. Breed Disposition to Disease in Dogs and Cats. Blackwell Publishing: Oxford; 2004.

15. Pettifor JM. Nutritional rickets: Deficiency of Vitamin D, calcium, or both? American Society of Clinical Nutrition. 2004;80(6): 17255-17295.

16. Cunningham J, Locatelli F, Rodriguez M. Secondary hyperparathyroidism: Pathogenesis, disease progress, and therapeutic options. Clinical Journal of the American Society of Nephrology. 2011; 6(4): 913-921.

17. Svihla A. Carries in the Hawaiian Poi Dog. Occasional Papers of the Bernice P. Bishop Museum Honolulu Hawaii. 1957; XXII(2):1-8.
18. Brosses C de (1709-1777), Callander J (1766-1768) Terra Australia Cognita: Or voyages to the Terra Australis, or Southern Hemisphere, during the Sixteenth, Seventeenth and Eighteenth Centuries. A. Donaldson London \& Edinburgh. 17661768;1-3.

Available:http://tinyurl.com/okxlgzb

19. Stone OC. A few months in new Guinea. Harper: New York. 1879;69-94.

20. Yin S. A new perspective on barking in dogs (Canis familiaris). Journal of Comparative Psychology. 2002;116(2): 189-193.

21. Seksel K, Mazurski EJ, Taylor A. Puppy socialisation programs: Short and long term behavioural effects. Applied Animal Behaviour Science. 1999; 62(4):335-349.

22. Lyne C. New Guinea: An account of the establishment of the British Protectorate over the Southern Shores of New Guinea. London. 1885;34.

23. Coren $\mathrm{S}$. The intelligence of dogs: A guide to the thoughts emotions, and inner lives of our canine companions. Free Press: New York. 2005;139.

24. Bradshaw JWS, Goodwin D, Lea AM, Whitehead SL. A survey of the behavioural characteristics of pure-bred dogs in the United Kingdom. Veterinary Record. 1996; 138:465-468.

25. Best E. The Maori - Memoirs of the Polynesian Society v. 5. The Polynesian Society: Wellington, New Zealand. 1924; 244 [Photograph]

26. Newell J. Trading nature: Tahitians, Europeans and ecological exchange. University of Hawai'i Press: Honolulu. 2010;10,213.

27. Goderie R, Otten-Kerkdijk H, Helmer W, Widstrand $\mathrm{S}$. The Aurochs Born To Be Wild. Roodbont Publisher B.V: Zutphen; 2013.

28. Honolulu Advertiser \& Star Bulletin, 19291967. 'Kapiolani Park Zoo - Kapoho Hawaii' Volume III Honolulu Department of Public Works to Pianists: 166.

Available:http://tinyurl.com/peoemet

29. Honolulu Advertiser \& Star Bulletin. 'Kaneohe, Oahu - Kaplan, Abraham. 1929-1969;VI:A-Z: 193.

Available:http://tinyurl.com/lvns2jz

30. Honolulu Advertiser \& Star Bulletin. 'Disaster Relief - Dole Company. 19291969;VI:A-Z:105.

Available:http://tinyurl.com/l27buy6 
31. Throp Jl. People involvement innovations at the Honolulu Zoo. International Zoo Year Book. 1975;15(1):266-268.

32. Oskarsson M. Analysis of the Origin and Spread of the Domestic Dog Using YChromosome DNA and mtDNA sequence Data. Thesis (PhD)KTH Royal Institute of Technology, School of Biotechnology, Gene Technology.

Available:http://www.divaportal.org/smash/get/diva2:525521/INSIDE 01.2012

33. Wilmshurst JM, Hunt TL, Lipo CP, Anderson AJ. High precision radiocarbon dating shows recent and rapid initial human colonization of East Polynesia. PNAS. 2011;108(5):1815-1820.

34. Smith M. The archaeology of australia's deserts. Cambridge University Press: Cambridge; 2013.

35. Flannery T. Mammals of New Guinea. The Australian Museum: Robert and Brown Associates, Cornell University Press: New York; 1990.

36. Bulmer S. Lapita dogs and singing dogs and the history of the dog in new Guinea' in (eds.) Clark J R, Anderson A J, Vunidilo T. The Archaeology of Lapita Dispersal in Oceania: Papers from the Fourth Lapita Conference, June 2000. Pandanas Books: Canberra. 2001;183-201.

37. Koler-Matznick J, Brisbin, I L Jr, Feinstein M, Bulmer S. An Updated Description of the New Guinea Singing Dog (Canis Hallstromi, Troughton 1957). Journal of Zoological Society London. 2003;261:109118.

38. Koler-Matznick J, Yates BC, Bulmer S, Brisbin, IL Jr. The New Guinea singing dog: Its status and scientific importance. Australian Mammalogy. 2007;29:47-56.

39. Allen J. Nebira 4: An early Austronesian site in Central Papua. Archaeology and Physical Anthropology in Oceania. 1972;7: 94-124.

40. Oskarsson MCR, Klütsch CFC, Boonyaprakob $\mathrm{U}$, Wilton $\mathrm{A}$, Tanabe $\mathrm{Y}$, Savolainen P. Mitochondrial DNA data indicate an introduction through Mainland Southeast Asia for Australian dingoes and Polynesian domestic dogs. Proceedings of the Royal Society B Epub; 2011.

DOI: 10.1098/rspb. 2011;1395

41. Savolainen $P$, Leitner $T$, Wilton $A N$, Matisoo-Smith E, Lundeberg J. A detailed picture of the origin of the Australian Dingo, Obtained from the Study of mitochondrial DNA. PNAS. 2004;101(33): 12387-12390

DOI: 10.1073/pnas.0401814101

42. Ardalan A, Oskarsson M, Natanaelsson C, Wilton AN, Ahmadian A, Savolainen P. Narrow genetic basis for the Australian Dingo Confirmed Through Analysis of paternal ancestry. Genetica. 2012;140:6573.

43. Sacks BN, Brown SK, Stephens D, Pedersen NC, Wu JT, Berry OY Chromosome analysis of dingoes in southeast asian village dogs suggests a neolithic continental expansion from Southeast Asia followed by multiple Austronesian dispersals. Molecular Biology and Evolution. 2013;30:1103-1118.

44. Diamond J. Express train to Polynesia. Nature. 1988;336:307-308

45. Diamond J. Polynesian origins: Slow boat to Melanesia? (Reply to S. Oppenheimer \& M. Richards). Nature. 2001;410:167.

46. Wilson DE, Reeder DM. Mammal species of the World - A taxonomic and geographic reference. $3^{\text {rd }}$ Edition, John Hopkins University Press: Baltimore; 2005.

47. Kirch P V, Green R C Hawaiki, Ancestral Polynesia - An Essay in Historical Anthropology. Cambridge University Press: Cambridge; 2001.

48. Pollock NJ. Food classification in three pacific societies: Fiji, Hawaii and Tahiti. Ethnology. 1986;25(2):107-117.

49. Podberscek AL. Good to pet and eat: The keeping and consuming of dogs and cats in South Korea. Journal of Social Issues. 2009;65(3):615-632.

50. Driscoll D, Macdonald DW. Top dogs: Wolf domestication and wealth. Journal of Biology. 2010;9(10):1-6.

51. Kahn M. Always hungry, never greedy Food and the expression of gender in Melanesian society. Cambridge University Press: Cambridge; 1986.

52. Pukui K. Games of my Hawaiian childhood. California Folklore Quarterly. 1943;2(3):205-220.

53. Green LC, Beckwith MW. Hawaiian customs and beliefs relating to sickness and death. American Anthropologist. 1926; 28(1):176-208.

54. Beckwith $\mathrm{M} \mathrm{W}$. The Hawaiian romance of Laieikawai. 33(r)d Annual Report of the Bureau of American Ethnology to the secretary of the Smithsonian Institute 1911-12 Washington Government Printing Office. 1919;285-667. 
55. Buffet G, Buffet P. PuaPuaLenaLena and the Magic Kiha-pu. Island Heritage: Honolulu; 1984.

56. Turner G. Samoa - A hundred years ago and long before together with notes on the cults and customs of twenty three other Islands in the Pacific. Macmillan and Co.: London; 1884.

57. Kirch PV. On the road of the winds: An archaeological history of the Pacific Islands before European Contact. University of California Press: Berkeley, Los Angeles, London; 2002.

58. Kent HW. Treasury of Hawaiian words in one hundred and one categories. Masonic Public Library: Hawaii; 1986.

59. Emory KP, Bonk WJ, Sinoto YH. Hawaiian archaeology: Fishhooks B. $\mathrm{P}$ Bishop Museum Special Publication 49: Honolulu; 1959.

60. Rose RG. Taumi gorgets from the Society Islands. in Dark $P$ J C (eds) Artistic Heritage in a Changing Pacific. Hawaii University Press: Honolulu. 1993;91-105.

61. Jacomb C. The chronology of Moncks, Canterbury New Zealand. Records of the Canterbury Museum. 2008;22:45-46.

62. Stasack E, Dorn R I, Lee G. First direct $\mathrm{C}^{14}$ ages on Hawaiian Petroglyphs. Asian Perspectives. 1996;35(1):51-72.

63. Neich R. Samoan figurative carvings and taumualua canoes - A further note. The Journal of Polynesian Society. 1991; 100(3):317-328.

64. Farris P. Dog petroglyphs, Nu'uannu, Honolulu, Oahu, Hawaii. Rock Art by Peter Farris; 2010. [Photograph] Shared with permission

Available:http://rockartblog.blogspot.co.uk/ search?q=Hawaii

(Accessed 19th March 2015)
65. Smith DP. Breastfeeding, contraception, and birth intervals in developing countries. Studies in Family Planning. 1985;16(3): 154-163.

66. Dewees WP. A treatise on the physical and medical treatment of children. Part 516. Carey H C, Lea I eds. Philadelphia. PA; 1825.

67. Radbill Samuel $X$. The role of animals in infant feeding. In Hand, Wayland D. American Folk Medicine: A Symposium. University of California Press; 1976.

68. Sillitoe P. An introduction to the anthropology of melanesia culture and tradition. Cambridge University Press: Cambridge; 1998.

69. Anderson A. Pre-European hunting dogs in the South Island, New Zealand. New Zealand Journal of Anthropology. 1981;3: 15-20.

70. Mariner W. An account of the natives of the Tonga Islands. C Ewer; 1820.

71. Sax DF, Gaines SD. Species invasion and extinction: the future of native biodiversity on islands PNAS. 2008;105(1):1149011497.

72. Atkinson IAE. A reassesment of factors, particularly Rattus rattus $\mathrm{L}$. that influence the decline of endemic forest birds in the Hawaiian Islands. Pacific Science. 1977; 31(2):109-133.

73. Morey DF. Dogs domestication and the development of a social bond. Cambridge University Press: Cambridge; 2010.

74. Mitchell P. Did disease constrain the spread of domestic dogs (Canis familiaris) into Sub-Saharan Africa? Azania: Archaeological Research in Africa. 2015; 50(1):92-135.

(c) 2018 Williams et al.; This is an Open Access article distributed under the terms of the Creative Commons Attribution License (http://creativecommons.org/licenses/by/4.0), which permits unrestricted use, distribution, and reproduction in any medium, provided the original work is properly cited.

Peer-review history:

The peer review history for this paper can be accessed here: http://www.sciencedomain.org/review-history/23786 